\title{
Rubiacearum Americanarum Magna Hama Pars XXVIII: New Taxa, New Combinations, New Names, and Lectotypification for Several Species Found in Mexico and Central America
}

\author{
Charlotte M. Taylor \\ Missouri Botanical Garden, P.O. Box 299, St. Louis, Missouri 63166-0299, U.S.A. \\ charlotte.taylor@mobot.org \\ Joaquín Sánchez-González \\ Museo Nacional de Costa Rica, Apartado Postal 749-1000, San José, Costa Rica. \\ jsanchez@museocostarica.go.cr

\section{Barry Hammel}

Missouri Botanical Garden, P.O. Box 299, St. Louis, Missouri 63166-0299, U.S.A., and Instituto Nacional de Biodiversidad (INBio), Apdo. 22-3100, Santo Domingo, Heredia, Costa Rica.

barry.hammel@mobot.org

David H. Lorence

National Tropical Botanical Garden, 3530 Papalina Road, Kalaheo, Kauai, Hawaii 96741, U.S.A. lorence@ntbg.org

Claes Persson

Department of Plant and Environmental Sciences, University of Gothenburg, Box 461, SE-405 30 Göteborg, Sweden. claes.persson@dpes.gu.se

\section{Piero G. Delprete}

Herbier de Guyane, Institut de Recherche pour le Développement (IRD), Boîte Postale 165, 97323

Cayenne Cedex, French Guiana, France. piero.delprete@ird.fr

\section{Roy E. Gereau}

Missouri Botanical Garden, P.O. Box 299, St. Louis, Missouri 63166-0299, U.S.A.

roy.gereau@mobot.org

Abstract. The Neotropical genus Borojoa Cuatrec. (Rubiaceae) is now considered a synonym of Alibertia A. Rich. ex DC. Consequently, three species named in Borojoa and found in Costa Rica and Panama are transferred to Alibertia with these corresponding nomenclatural changes: the new combination $A$. atlantica (Dwyer) Delprete \& C. H. Perss. is based on $B$. atlantica Dwyer, the new name $A$. dwyeri Delprete \& C. H. Perss. is provided for $B$. panamensis Dwyer, and the new combination A. patinoi (Cuatrec.) Delprete \& C. H. Perss. is provided for B. patinoi Cuatrec. Additionally, the species A. premontana C. M. Taylor is reduced to a variety of A. edulis (Rich.) A. Rich. ex DC., as A. edulis var. premontana (C. M. Taylor) Delprete \& C. H. Perss. A lectotype is selected for $A$. edulis. The recent publication of
Arachnothryx chimalaparum Lorence ex Borhidi designated a holotype deposited at MO, but no such specimen has been located; a lectotype is here chosen based on a duplicate of the holotype deposited at MEXU. The new species Notopleura recondita Hammel \& C. M. Taylor of the Osa Peninsula of Costa Rica can be distinguished from N. polyphlebia (Donn. Sm.) C. M. Taylor by its leaf blades with the secondary veins plane on the adaxial surface and its short cymose or paniculiform inflorescences. The new species Palicourea matamana C. M. Taylor of premontane forests of centraleastern Costa Rica can be separated from P. orosiana C. M. Taylor by its larger stipules, longer calyx lobes, and hirsute pubescence. The new species $P$. providenciana J. Sánchez-Gonz. \& C. M. Taylor of 
montane forests in south-central Costa Rica can be separated from $P$. hammelii C. M. Taylor by its longer lanceolate stipule lobes, dark purple or yellowflushed inflorescences, and shorter calyx lobes. The Panamanian plants treated previously as Psychotria acuminata subsp. boraginoides Dwyer are here considered to differ at the species level from $P$. acuminata Benth., and accordingly the new combination P. boraginoides (Dwyer) C. M. Taylor is here published for this species. Clarification of the identity of Cephaelis croatii Dwyer shows that it is a distinct species of Psychotria, and the new combination $P$. croatii (Dwyer) C. M. Taylor is published here for this species. The new species $P$. herrerana $C$. M. Taylor of central Costa Rica can be recognized by its combination of large, sessile, elliptic leaves, its large paniculiform inflorescences, and its relatively small corollas. Study of the Costa Rican plants previously called Rudgea thyrsiflora Donn. Sm. shows that these do not have the characters of Rudgea, but are similar to Psychotria racemosa Rich. and better included in this latter genus; the new name $P$. tsakiana C. M. Taylor is here published for this species. The new combination Simira panamensis (Dwyer) C. M. Taylor is published here based on the name Bathysa panamensis Dwyer, which has priority over the name $S$. darienensis Dwyer; both of the names Dwyer published are based on the same type specimen, thus the later name $S$. darienensis is illegitimate.

Resumen. El género neotropical Borojoa Cuatrec. (Rubiaceae) ahora se considera un sinónimo de Alibertia A. Rich. ex DC., por lo tanto las tres especies con nombres en Borojoa que se encuentran en Costa Rica y Panama se transfieren a Alibertia con los cambios nomenclaturales correspondientes: la combinación nueva A. atlantica (Dwyer) Delprete \& C. H. Perss. se basa en B. atlantica Dwyer, el nombre nuevo A. dwyeri Delprete \& C. H. Perss. se publica para B. panamensis Dwyer, y la nueva combinación A. patinoi (Cuatrec.) Delprete \& C. H. Perss. se publica para $B$. patinoi Cuatrec. Además la especie A. premontana C. M. Taylor se rebaja a una variedad de A. edulis (Rich.) A. Rich. ex DC., con el nombre $A$. edulis var. premontana (C. M. Taylor) Delprete \& C. H. Perss. Se escoge un lectotipo para A. edulis. Para la especie recientemente descrita Arachnothryx chimalaparum Lorence ex Borhidi designó un holotipo depositado en MO, pero tal espécimen no se ha ubicado; aquí se escoge como lectotipo un duplicado del holotipo en MEXU. La especie nueva Notopleura recondita Hammel \& C. M. Taylor de la Península de Osa de Costa Rica se distingue de $N$. polyphlebia (Donn. Sm.) C. M. Taylor por las láminas foliares con las venas secundarias planas en el haz y las cortas inflorescencias cimosas o paniculiformes. La especie nueva Palicourea matamana C. M. Taylor de bosques premontanos del centro-este de Costa Rica se distingue de $P$. orosiana $\mathrm{C}$. M. Taylor por las estípulas más grandes, los lóbulos del cáliz más largos y la pubescencia hirsuta. La especie nueva $P$. providenciana J. Sánchez-Gonz. \& C. M. Taylor de bosques montanos en el sur-central de Costa Rica se distingue de P. hammelii C. M. Taylor por los lóbulos de las estípulas lanceolados y más largos, las inflorescencias de color morado oscuro o matizado con amarillo y los lóbulos del cáliz más cortos. Las plantas panameñas anteriormente tratadas en Psychotria acuminata subsp. boraginoides Dwyer aquí se consideran diferentes de $P$. acuminata Benth. al nivel de especie, entonces la combinación nueva $P$. boraginoides (Dwyer) C. M. Taylor se publica aquí para esta especie. La clarificación de la identidad de Cephaelis croatii Dwyer demuestra que es una especie diferente de Psychotria, y la combinación nueva $P$. croatii (Dwyer) C. M. Taylor se publica aquí para esta especie. La especie nueva $P$. herrerana $C$. M. Taylor del centro de Costa Rica se reconoce por la combinación de las hojas grandes, sésiles y elípticas, las grandes inflorescencias paniculiformes y las corolas relativamente pequeñas. El estudio de las plantas costarricenses anteriormente llamadas Rudgea thyrsiflora Donn. Sm. demuestra que éstas no tienen los carácteres de Rudgea y son similares a Psychotria racemosa Rich., entonces se incluyen mejor in este segundo género; el nombre nuevo $P$. tsakiana C. M. Taylor se publica aquí para esta especie. La combinación nueva Simira panamensis (Dwyer) C. M. Taylor se publica aquí basado en el nombre Bathysa panamensis Dwyer, lo cual tiene prioridad sobre el nombre $S$. darienensis Dwyer; ambos de los nombres publicados por Dwyer se basan en el mismo espécimen tipo, entonces el nombre posterior $S$. darienensis es ilegítimo.

Key words: Alibertia, Arachnothryx, Bathysa, Borojoa, Cephaelis, Colombia, Costa Rica, Gardenieae, IUCN Red List, Mexico, Neotropical floristics, Notopleura, Palicourea, Palicoureeae, Panama, Psychotria, Psychotrieae, Rubiaceae, Rudgea, Simira.

Recent botanical exploration in southern Central America has added significantly to our knowledge of the flora of this region. Here we describe several new species and publish several taxonomic changes for the Rubiaceae of this region, in preparation for the upcoming publication of the Rubiaceae treatments for the Flora Mesoamericana and the Manual de Plantas de Costa Rica projects. 


\section{Methods}

The genera and species studied here are arranged in alphabetical order. Authorship of sections on individual genera here varies and is indicated for each section. Additional collection data for most of the specimens cited here are available at $<$ http:// www.tropicos.org $>$, along with high-resolution digital images of the type specimens of the newly described species.

\section{Conservation status assessment methodolo-} gy. The study presented here is taxonomic and floristic: the objective is enumeration of the species that belong to various Rubiaceae genera, and of the species that occur in the area of tropical Central and South America. The methods employed here correspond only to this objective; thus this study is based on survey of specimens collected over a number of years using varied survey methods aimed at various objectives. The specimens here used to delineate the range and commonness of these new species were located through a nonexhaustive survey of several herbaria, and no field studies have been done targeting the occurrence of these species where they are known or expected to grow. Thus the floristic information presented here is a simplified presence report based on incomplete survey of the available data, which are uneven and incomplete for this region (Schulman et al., 2007). Knowledge of the true geographic range and the population size and dynamics of a species are essential to understanding the threats to its existence, and thus to understanding its actual conservation status; documentation of the existence of a species based on one or several museum collections does not provide adequate data to evaluate these factors. Conservation assessments are provided here for these newly described species using IUCN categories and criteria (IUCN, 2001) based on the totality of our current knowledge. The basis for these assessments in the form of a map and the calculated assessment parameters are available under the corresponding species names at $<$ http:// www.tropicos.org $>$. The assessment parameters were calculated using the IUCN Rating tool (Moat, 2007) in ArcView GIS 3.2 (ESRI, 1999), with the grid cell size used for calculating Area of Occupancy (AOO) varied between 1 and $3.16 \mathrm{~km}$ depending on characteristics of the species and data (IUCN Standards and Petitions Working Group, 2008). These assessments are not being submitted to IUCN for publication on the Red List $(<\mathrm{http}: / /$ www.iucnredlist.org $>$ ), and the basis for these assessments should be carefully evaluated by the reader.

\section{TAXONOMY}

NEW COMBINATIONS AND A NEW NAME IN ALIBERTIA*

Cuatrecasas (1953) and Steyermark (1966) distinguished Borojoa Cuatrec. from Alibertia A. Rich. ex DC. by having entirely fleshy fruit, heteromorphous flowers with a thicker corolla, flowers subtended by two stipulelike bracts, and stipules partially connate at the base. However, detailed study of the group revealed that the three latter characters also occur in Alibertia, and that several Borojoa species, as well as many Alibertia species, also have a woody mesocarp. In a phylogenetic analysis using nuclear ribosomal DNA sequences of the ITS and $5 \mathrm{~S}$ regions, the genus Borojoa appeared nested inside Alibertia s. str. (Persson, 2000), which consequently becomes paraphyletic if Borojoa is treated separately. Therefore, from the evidence presented, it is concluded that Borojoa is better included within Alibertia. For the forthcoming account of Rubiaceae for the Flora Mesoamericana, two new combinations and one new name are here proposed. In addition, A. premontana C. M. Taylor is here lowered to a variety of A. edulis (Rich.) A. Rich. ex DC., as the original differentiating characters are not complete when considering the species over its entire distribution range.

1. Alibertia atlantica (Dwyer) Delprete \& C. H. Perss., comb. nov. Basionym: Borojoa atlantica Dwyer, Ann. Missouri Bot. Gard. 67: 46. 1980. TYPE: Panama. Colón: 2-3 mi. up Río Guanche, 10-20 m, 19 Jan. 1973 (fr.), H. Kennedy \& R. Foster 2197 (lectotype, designated by Lorence [1999: 19], MO 2163702 [sheet 2 of 2]; isotypes, F, MO 2163702 [sheet 1 of 2], PMA not seen).

Discussion. The two sheets of Kennedy \& Foster 2197 at MO have the same sheet accession number, MO 2163702, and apparently Dwyer (1980) had intended both sheets to comprise the holotype, although this is not noted in his protologue. However, the two sheets are similar and not complementary, as each consists of two leaf pairs and a single sectioned fruit. Because of this ambiguity, sheet 2 of 2 was selected by Lorence (1999) as holotype because it is

*This section authored by Piero G. Delprete and Claes Persson. 
slightly more complete and representative, with a fruit cut into three sections and a portion of stem bearing two well-spaced leaf pairs. Lorence's designation is here considered effective lectotypification.

Alibertia atlantica is a small to medium-sized tree, distributed from Nicaragua to Panama, and characterized by leaf blades with (nine to)11(or 12) pairs of secondary veins and fruits with a woody mesocarp. It is closely related to A. dwyeri Delprete \& C. H. Perss. (see below), but distinguished by its relatively short petioles ([5-]10-18 mm long vs. [5-]10-27 $\mathrm{mm})$, persistent elliptic stipules with an acute apex (vs. subcaducous, slightly obovate to obovate, rarely elliptic, with an acuminate apex), and leaf blades that usually dry dark brown (vs. drying brown to brownish olive-green). In addition, A. atlantica seems to occur in lowland forests, below $400 \mathrm{~m}$, whereas A. dwyeri seems to prefer cloud forests at 600-900 m altitude.

The type of Alibertia atlantica belongs to a somewhat isolated population in central Panama and differs morphologically from the Costa Rican populations in its olive-green leaf blades when dry and its sparsely puberulent fruits.

Selected specimens examined. COSTA RICA. Heredia: Puerto Viejo de Sarapiquí, Finca Tropical, Beach 1488 (MO). NICARAGUA. Río San Juan: Reserva Indio-Maiz, Mpio. Juan del Norte, Cerro el Gigante del Río San Juan, $10^{\circ} 46^{\prime} \mathrm{N}, 83^{\circ} 53^{\prime} \mathrm{W}, 100-200 \mathrm{~m}$, R. Rueda et al. 8871 (MO). PANAMA. Colón: Río Guanche, ca. $2 \mathrm{~km}$ upstream from bridge, Kennedy et al. 3411 (US).

2. Alibertia dwyeri Delprete \& C. H. Perss., nom. nov. Replaced synonym: Borojoa panamensis Dwyer, Phytologia 17: 446. 1968, non Alibertia panamensis L. Riley, Bull. Misc. Inform. Kew 1927: 123 [=Alibertia edulis (Rich.) A. Rich. ex DC., Prod. (DC.): 4: 443. 1830.]. TYPE: Panama. Coclé: Cerro Pilon [Pilón], El Valle, 4 Jan. 1968 (fr.), J. A. Duke \& B. R. Lallathin 15014 (holotype, MO 1968459; isotype, MO 2163702).

Discussion. In the original description, the isotype was cited as an additional specimen. The information on the original label of the isotype is scanty and includes only that the specimen was collected at Cerro Pilón at $2700 \mathrm{ft}$. [ca. $823 \mathrm{~m}$ ] by B. R. Lallathin in 1968, coll. no. 15014. According to an additional label added by C. M. Taylor, the original label was probably mistyped, as the digit " 1 " seems to be added afterward in front of "5014." Also, the elevation note " $2700 \mathrm{ft}$. " is lacking on the holotype. The label of the holotype also gives the following information: "Tree fruits green; probably edible when ripe. Fruit, when sawed into, blackening as if possessed of genipine." The protologue reads that the holotype was collected by Duke and Dwyer, an error that was corrected by Dwyer (1980) in his treatment of Rubiaceae for the Flora of Panama. The specific epithet is dedicated to John D. Dwyer (19152005), specialist in Neotropical Rubiaceae (and who first described this species). Dr. Dwyer worked for more than 30 years at St. Louis University and the Missouri Botanical Garden, and realized more than 30 expeditions to remote areas of Belize, Guatemala, and Panama (for his biography, see Croat et al., 2006).

Alibertia dwyeri is a common tree in the understory of cloud forests of Panama, at 600-900 m altitude. It is similar to A. utleyorum (Dwyer) C. M. Taylor in having acuminate stipules and elliptic to broadly elliptic or slightly obovate leaf blades, but differs by the leaf blades being glabrous or sometimes minutely puberulent on the midvein and secondary veins abaxially (vs. velutinous or hirsutulous abaxially), the glabrous fruits (vs. densely velutinous-puberulent or glabrate), and the dentate or jagged calyx margin (vs. distinctly lobate). For a comparison with A. atlantica, see above.

Selected specimens examined. PANAMA. Coclé: Along rd. betw. Llano Grande \& Coclesito, N of Pintada, $6 \mathrm{~km} \mathrm{~N}$ of Llano Grande, 600 m, Antonio 3605 (MO); Cerro Pilón, Dwyer 8341 (MO). Panamá: Cerro Campana above Su Lin Motel, Croat 14779 (F, MO, NY).

3. Alibertia edulis (Rich.) A. Rich. ex DC., Prod. (DC.) 4: 443. 1830. Basionym: Genipa edulis Rich., Actes Soc. Hist. Nat. Paris 1: 107. 1792. TYPE: Guyane Françoise [French Guiana]. S. loc., 1792, Le Blond s.n. (lectotype, designated here, $\mathrm{P})$.

Discussion. Lorence (1999) indicated that the type of this taxon was collected by L. C. Richard. However, based on additional evidence it is apparent that the type material was instead collected by Le Blond in French Guiana and described shortly after by Louis Claude Richard. As L. C. Richard was in French Guiana after the publication of Genipa edulis Rich., it is impossible that he collected the type material. There is a sheet at the $\mathrm{P}$ herbarium that corresponds entirely to this, and it is here selected as lectotype in accordance with the International Code of Botanical Nomenclature (McNeill et al., 2006: Art. 9.9). 


\section{3a. Alibertia edulis var. edulis.}

Selected specimens examined. NORTH AMERICA. MEXICO. Chiapas: Mun. Arriaga, $6 \mathrm{~km} \mathrm{~N}$ of Arriaga, 250 $\mathrm{m}$, Breedlove 27291 (NY).

CENTRAL AMERICA. BELIZE. Dist. Toledo: Punta Gorda, near Manuel Sam's house, $16^{\circ} 08^{\prime} \mathrm{N}, 88^{\circ} 53^{\prime} \mathrm{W}, 200$ $\mathrm{m}$, Cordero et al. 22 (NY). COSTA RICA. Reserva Forestal de San Ramón, $10^{\circ} 12^{\prime} 53^{\prime \prime}, 84^{\circ} 36^{\prime} 28^{\prime \prime} \mathrm{W}, 800-1000 \mathrm{~m}$, Herrera \& Mora 195 (MO). Guanacaste: Guanacaste mtn. range, Maritza station, slopes of Volcano Orosi, $10^{\circ} 57^{\prime} 40^{\prime \prime} \mathrm{N}, 85^{\circ} 29^{\prime} 40^{\prime \prime} \mathrm{W}, 600 \mathrm{~m}$, Ramirez et al. 47 (GB). EL SALVADOR. Chalatenango: vic. San Ignacio, 3000 ft. [914 m], Allen 7043 (F, NY). Morazán: Río Sapo, $13^{\circ} 55^{\prime} 66^{\prime \prime} \mathrm{N}, 88^{\circ} 5^{\prime} 86^{\prime \prime W}, 670 \mathrm{~m}$, Monro et al. 2807 (PTBG). GUATEMALA. Izabal: Ensenda Los Lagartos, 1 m, Stevens et al. 25320 (MO). HONDURAS. Francisco Morazán: Jicarito River, drainage of Río Yeguare, $14^{\circ} \mathrm{N}$, $87^{\circ} \mathrm{W}, 800 \mathrm{~m}$, Glassman 1721 (F, NY). NICARAGUA. Chinandega: 3-4 km SE of San Pedro de Potrero Grande, Los Laureles, $13^{\circ} 15^{\prime} \mathrm{N}, 86^{\circ} 53^{\prime} \mathrm{W}, 340-400 \mathrm{~m}, 28$ Sep. 1981 (fr.), Moreno 11701 (NY). PANAMA. Panamá: Cerro Colorado, rd. to Bocas del Toro, end of $\mathrm{mtn}$. access rd. just above face of mine, 1600-1700 m, Folsom et al. 4740 (MO).

SOUTH AMERICA. BOLIVIA. Beni: Ballivián, Serranía Pilon Lajas, $24 \mathrm{~km}$ SO of Yucumo, on rd. YucumoQuiquibe, $15^{\circ} 15^{\prime} \mathrm{S}, 67^{\circ} 00^{\prime} \mathrm{W}, 850-900 \mathrm{~m}$, Killeen et al. 2981 (MO). BRAZIL. Chapada do Veadeiros [Goias]: Mun. Alto Paraiso, ca. $25 \mathrm{~km}$ N of Alto Paraiso, $1700 \mathrm{~m}$, Anderson et al. $6689(\mathrm{NY})$.

3b. Alibertia edulis var. premontana (C. M. Taylor) Delprete \& C. H. Perss., comb. et stat. nov. Basionym: Alibertia premontana C. M. Taylor, Novon 6: 215, fig. 1. 1996. TYPE: Costa Rica. Alajuela: Reserva Biol. Monteverde, Valle del Río Peñas Blancas, fila del Toro, Sendero Pipilacha y Campo Tres, $10^{\circ} \mathrm{N}, 84^{\circ} \mathrm{W}, 900-$ 1100 m, 21 Jan. 1991 (fr.), W. Haber \& E. Cruz 10630 (holotype, MO 4234216; isotypes, CR not seen, F, INB).

Discussion. Alibertia edulis var. premontana differs primarily from variety edulis by its leaf blades that are matte adaxially and glabrous abaxially (vs. usually glossy adaxially and glabrous or puberulent abaxially) and its short stipules (4-7[-11] mm long vs. 5-15[-22] mm long). Alibertia edulis var. premontana occurs in wet premontane forests at 800-1700 m, whereas variety edulis normally occurs below $500 \mathrm{~m}$, but may reach $1000 \mathrm{~m}$ in Costa Rica and Panama, and up to $1700 \mathrm{~m}$ in central Brazil.

Selected specimens examined. COSTA RICA. Puntarenas: Bosque Eterno de Los Niños, Río Peñas Blancas, Quebrada Gata, Riachuelo de Fernando Villalobos, $10^{\circ} 23^{\prime} \mathrm{N}, 84^{\circ} 42^{\prime} \mathrm{W}, 1100 \mathrm{~m}$, Bello et al. 2172 (F, INB, MO); Cantón Parrita, Cuenca del Pirris-Damas, cabeceras Río Palo Seco, camino a Fila Chonta, $09^{\circ} 35^{\prime} \mathrm{N}, 84^{\circ} 09^{\prime} \mathrm{W}$,
1050-1300 m, Morales \& Rodríguez 6453 (INB). San José: Turrubares, mtn. slope of Cerro Bares, $09^{\circ} 47^{\prime} \mathrm{N}, 84^{\circ} 28^{\prime} \mathrm{W}$, $1550 \mathrm{~m}$, Jiménez et al. 836 (INB [2], MO). PANAMA. Bocas del Toro: Chiriquí-Bocas del Toro border, vic. Cerro Colorado, along mining rd. on divide, $08^{\circ} 35^{\prime} \mathrm{N}, 81^{\circ} 50^{\prime} \mathrm{W}$, 1300-1400 m, McPherson 13644 (MO). Chiriquí/Bocas del Toro border: Cerro Colorado, rd. to Bocas del Toro, end of $\mathrm{mtn}$. access rd. just above face of mine, 1600-1700 m, Folsom et al. 4740 (MO), 4743 (MO). Chiriquí: Fortuna Dam, 1400-1600 m, Folsom et al. 5606 (MO); Valley of El Hornito, vic. Fortuna Dam, along trail down from hwy., $08^{\circ} 45^{\prime} \mathrm{N}, 82^{\circ} 15^{\prime} \mathrm{W}, 1100-1300 \mathrm{~m}$, McPherson 12525 (MO).

4. Alibertia patinoi (Cuatrec.) Delprete \& C. H. Perss., comb. nov. Basionym: Borojoa patinoi Cuatrec., Secr. Agric. Ganad. Colomb. Serv. Divulg. Ser. Bot. Aplic. 2: 4741949 [preprint of Rev. Acad. Colombia Ci. Exact. 7: 474. 1950]. TYPE: Colombia. El Valle: Río Calima (región de Chocó), rt. margin betw. Quebrada de la Brea \& La Esperanza, 25 m, 19 May 1946, J. Cuatrecasas 21137 (holotype, F 1251558; isotypes, F [3], US).

Discussion. Alibertia patinoi is a shrub, treelet, or tree with a natural distribution ranging from Costa Rica through Panama, along the Pacific coast of the Chocó Region of Colombia to the province of Esmeraldas, Ecuador. It is often cultivated in the Chocó Region for its large, edible fruits (locally called borojó) and occasionally also in the Amazonian region of Colombia and Ecuador. This species is characterized by its large stipules ([19-]25-35[-45] $\mathrm{mm}$ long), glabrous leaves with (9 to) 12 to 17 pairs of secondary veins, 5- or 6(7)-merous male flowers, 7- to 9-merous female flowers, stout corollas, and large fruits with a thick, fleshy mesocarp.

Selected specimens examined. CENTRAL AMERICA. COSTA RICA. Puntarenas: Osa Peninsula, Cantón Golfito, Parque Nac. Corcovado, Est. Los Patos, Sendero Sirena, $08^{\circ} 43^{\prime} \mathrm{N}, 83^{\circ} 3^{\prime} \mathrm{W}, 200 \mathrm{~m}$, Aguilar 3315 (F[2], INB, NY). PANAMA. Darién: Santa Fé, Bristan 310 (MO).

SOUTH AMERICA. COLOMBIA. Chocó: Mun. Riosucio, Zona de Urabá, Cerros de Cuchillo, Piedmont de Cerro, 100 m, Cárdenas 1867 (MO). ECUADOR. Esmeraldas: Cantón San Lorenzo, La Chiquita Exp. For. Station, $01^{\circ} 38^{\prime} \mathrm{N}, 78^{\circ} 45^{\prime} \mathrm{W}$, Persson \& Nordenhäll 429 (GB, QCNE).

ARACHNOTHRYX PLANCH.: LECTOTYPIFICATION OF THE NAME ARACHNOTHRYX CHIMALAPARUM*

In his publication on the Rubiaceae of Mexico, Borhidi (2006: 45, 479) described the new species

*This section authored by David H. Lorence. 


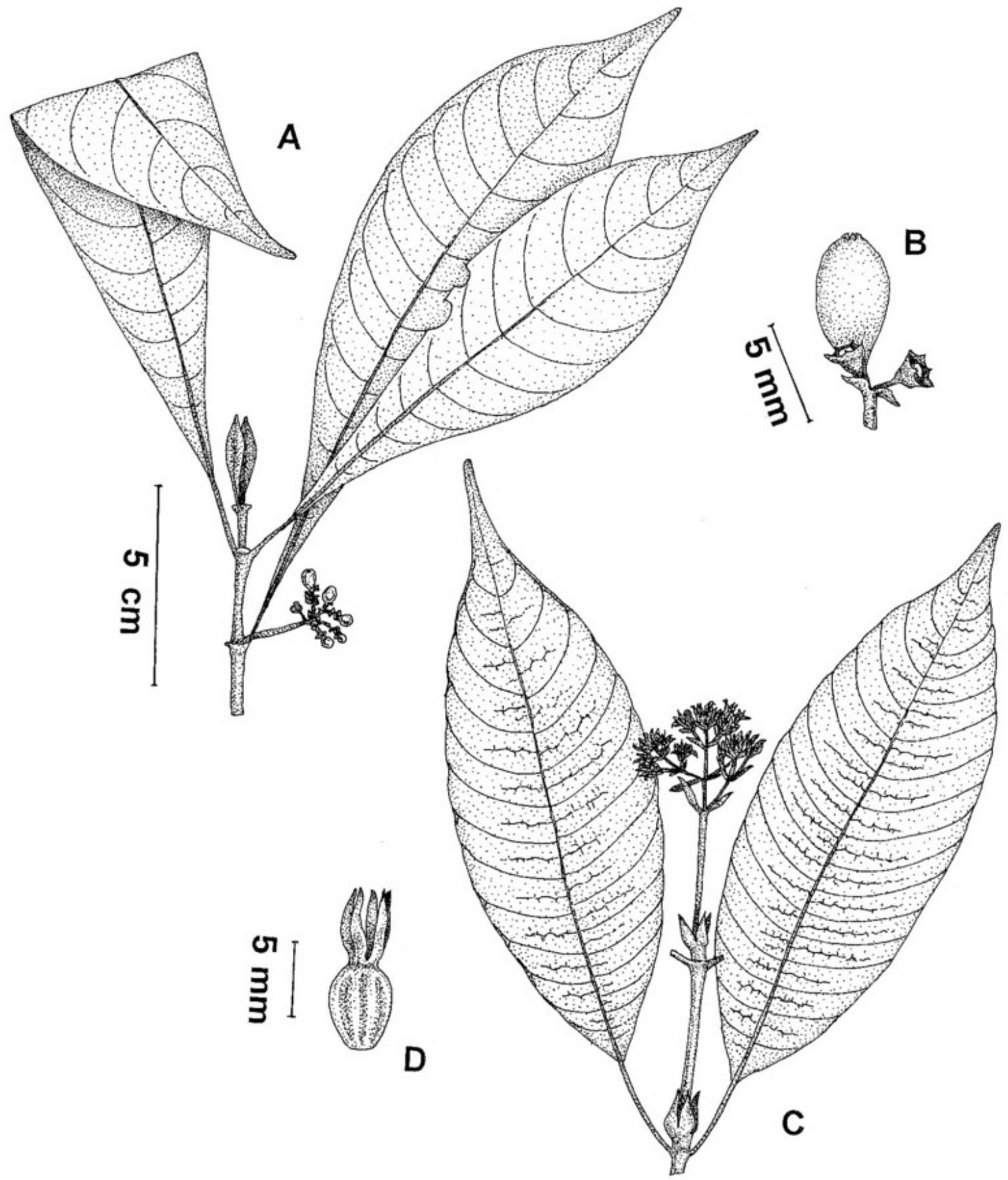

Figure 1. A, B. Notopleura recondita Hammel \& C. M. Taylor; based on the paratype Hammel 18287 (F). - A. Portion of branch with infructescence with young fruits. - B. Portion of infructescence with one developing fruit and two flowers from which corollas have fallen. C, D. Palicourea providenciana J. Sánchez-Gonz. \& C. M. Taylor. -C. Portion of branch with old inflorescence; based on the paratype Rodriguez et al. 8154 (INB). -D. Fruit; based on the paratype Martén \& Herrera 709 (F). $\mathrm{A}, \mathrm{C}$ drawn to same scale, indicated as $5 \mathrm{~cm}$.

Arachnothryx chimalaparum Lorence ex Borhidi based on the following specimen: "Mexico, Oaxaca, municipio de Santa María Chimalapa, Cerro de la Fortuna, Wendt et al. 5676." Borhidi apparently assumed that the specimen he designated as holotype was deposited at MO, stating in the protologue "holotipo: MO, isotipo: MEXU," but extensive searching by Taylor and Lorence at MO has failed to locate the specimen, suggesting that a duplicate was not sent to MO. According to the ICBN (McNeill et al., 2006: Art. 9.9), if the holotype is lost or destroyed, a lectotype should be designated. The cited isotype collection was located at MEXU and was seen by Borhidi. A digital image of this specimen was seen by Lorence. Wendt's collections were distributed from the Colegio de Postgraduados, Montecillos at Chapingo, Mexico, from the CHAPA herbarium where a duplicate also exists. Another 
duplicate of this collection has been located at TEX, and a fourth duplicate of this collection was sent to Lorence for identification and is deposited in the herbarium of the National Tropical Botanical Garden (PTBG). The specimen at MEXU is here designated as the lectotype of $A$. chimalaparum, and the PTBG, CHAPA, and TEX specimens are designated as isotypes.

Arachnothryx chimalaparum Lorence ex Borhidi, Rubiáceas México 45. 2006. TYPE: Mexico. Oaxaca: mun. Santa María Chimalapa, Cerro de la Fortuna, un cerro de $1000 \mathrm{~m}$ en el SO de la Sa. Tres Picos, $17^{\circ} 1^{\prime} 30^{\prime \prime} \mathrm{N}, 94^{\circ} 37^{\prime} \mathrm{O}, 1000 \mathrm{~m}$, 28 Abr. 1987, T. Wendt, H. Hernández G., C. González L. \& C. Hernández G. 5676 (lectotype, designated here, MEXU 582265; isotypes, CHAPA, PTBG 013786, TEX).

\section{NOTOPLEURA: A NEW SPECIES FROM COSTA RICA*}

Notopleura (Oerst.) Bremek. comprises about 100 species of rather succulent, generally suffrutescent herbs and epiphytes found in wet tropical forests from Mexico and the Antilles to Bolivia and eastern Brazil. It was included by many authors in Psychotria L., but now appears more closely related to Palicourea Aubl.; Palicourea and related genera, including Notopleura, have sometimes been classified in a separate tribe from Psychotria, the Palicoureeae (Robbrecht \& Manen, 2006), though other authors have provisionally placed these all together until the entire group is better understood (Bremer \& Eriksson, 2009). The terrestrial species of Notopleura differ from Psychotria in their generally unbranched habit, succulent usually glandular stipules, and pseudoaxillary inflorescences (Taylor, 2001). Notopleura has a center of diversity in southern Central America, with more than a third of its species found in that region (Taylor, 2003); 24 species of Notopleura are known from Costa Rica, including the one newly described here. The description format and terminology here follow Taylor $(2001,2003)$. Keys to the species of Notopleura in Mesoamerica and Costa Rica will be presented in the forthcoming Rubiaceae treatments for the Flora Mesoamericana and Manual de Plantas de Costa Rica projects, respectively.

Notopleura recondita Hammel \& C. M. Taylor, sp. nov. TYPE: Costa Rica. Puntarenas: cantón de Osa, Reserva Forestal de Golfo Dulce, fila entre

*This section authored by Barry Hammel, Charlotte M. Taylor, and Roy E. Gereau.
Rancho Quemado \& Drake, bosque alto a la par de camino, $8^{\circ} 42^{\prime} \mathrm{N}, 83^{\circ} 36^{\prime} \mathrm{W}, 350 \mathrm{~m}, 4$ July 2003, B. Hammel, I. Pérez \& J. Salazar 22841 (holotype, INB; isotypes, CR, USJ). Figure 1A, B.

Haec species a Notopleura polyphlebia (Donn. Sm.) C. M. Taylor foliorum venis secundariis adaxialiter laevibus atque inflorescentia ramosa distinguitur.

Succulent, erect, terrestrial herbs or soft shrubs to $0.5 \mathrm{~m}$ tall, rhizomatous; stems unbranched, glabrous. Leaves oblanceolate to elliptic, 10.5-25.5 × 2-5.8 $\mathrm{cm}$, apex acuminate, base acute to cuneate, drying papyraceous, adaxially glabrous and with darkened velvety appearance, abaxially puberulous to glabrescent and pale; costa prominulous adaxially, prominent abaxially; secondary veins 8 to 15 pairs, free or usually looping weakly to interconnect, adaxially plane, abaxially prominulous, with remaining venation plane and not visible on both surfaces; petioles $1-3 \mathrm{~cm}$, puberulous to glabrescent; stipules glabrous, sheath 1-1.5 mm, broadly rounded, deciduous, with 1 interpetiolar appendage inserted near base, broadly triangular, $1.5-2 \mathrm{~mm}$, succulent, flattened, acute to shortly erose, perhaps glandular, deciduous with or before sheath. Inflorescence pseudoaxillary, shortly paniculiform or cymose, apparently green, densely puberulous or hirtellous, ascending to spreading; peduncle $0.3-1.2 \mathrm{~cm}$; branched portion corymbiform to pyramidal, $0.5-2 \times 0.5-2 \mathrm{~cm}$, with secondary axes developed at 1 to 2 nodes, 2 per node, ascending, branched to 1 to 2 orders, dichasial; bracts triangular to linear, entire, those subtending secondary axes $2-3$ $\mathrm{mm}$, those subtending flowers $0.8-1 \mathrm{~mm}$. Flowers sessile and subsessile in glomerules of 2 to 5 at ends of axes; ovary obconic, ca. $0.5 \mathrm{~mm}$, glabrescent; calyx limb 0.5-1 mm, densely puberulous, 5 -lobed for 1/2$3 / 4$, lobes narrowly triangular; corolla in bud densely puberulous externally, with lobes 5 , smooth abaxially; stamens, style, and stigmas not seen. Infructescences similar to inflorescences. Immature fruits ellipsoid, ca. $6 \times 5 \mathrm{~mm}$, glabrescent, green becoming orange; pyrenes 2 , flattened, dorsally with 3 to 4 low sharp subequal longitudinal ridges and margins thickened.

Habitat, distribution, and phenology. Notopleura recondita is known from wet forests at $180-350 \mathrm{~m}$ on the Osa Peninsula in southern Costa Rica; it has been collected with flower buds in February, and with immature fruits in July and September.

IUCN Red List category. Notopleura recondita meets the criterion for Endangered based on its limited AOO and no more than five locations; because there are only two collecting localities, the Extent of Occurrence (EOO) cannot be calculated. 
This species is found entirely within one legally protected area, and overall is known from a small geographic region. It may be more common here than documented by specimens, as discussed in the comments below, because this species is easily overlooked. The habitats of this species are generally not in decline at the moment; therefore, it is assessed as Vulnerable due to its small range (VU D2). However, if the habitats of its range do begin to decline, then this species will become Endangered.

Discussion. This new species is distinguished within Notopleura by the combination of its terrestrial habit with the stems unbranched, its relatively small cymose or paniculiform inflorescences with the flowers grouped at the ends of the axes, and its flattened pyrenes with several low longitudinal ridges on the dorsal (i.e., abaxial) surface. Notopleura recondita belongs to Notopleura subg. Notopleura, which comprises the terrestrial Notopleura species with an unbranched habit (Taylor, 2001). This new species is only known from the Osa Peninsula in the Golfo Dulce region, an area of some endemism in Costa Rica, but also with phytogeographic relationships to lower and middle elevations of the eastern or Caribbean slopes of Costa Rica. These small understory plants are rare, even locally, and shade-loving with very dark green, matte leaves and the reproductive structures rather small and nondescript. Thus hidden, this species is easily overlooked and has been rarely collected, hence the specific epithet.

The fruits seen are apparently immature, based on their size and nonsucculent form, and the orange color reported for them may not be their color at maturity. Several species of this genus (e.g., Notopleura uliginosa (Sw.) Bremek., N. polyphlebia (Donn. Sm.) C. M. Taylor) have orange immature fruits that ultimately become black at maturity, though those mature fruits are rarely seen because the frugivores remove them very quickly after they change color; $N$. recondita may share this biology.

Due to its apparently axillary inflorescences and small stature, Notopleura recondita can be confused with Ronabea emetica (L. f.) A. Rich., which differs in its truly axillary inflorescences, i.e., present in both axils at each node, and blue to black fruits (Taylor, 2004). In its low, rhizomatous growth form, dark green velvety leaf surface, and orange immature fruits, $N$. recondita is similar to $N$. polyphlebia; however, N. polyphlebia can be recognized by its capitate inflorescences and oblongobovate leaves that are deeply plicate along the secondary veins, which are thinly prominent on the adaxial surface.
Paratypes. COSTA RICA. Puntarenas: cantón Osa, Reserva Forestal de Golfo Dulce, en el $\mathrm{S}$ del valle de Rancho Quemado, ca. $15 \mathrm{~km} 0$ de Rincón, B. Hammel, H. Kennedy \& J. Solomon 17865 (CR, F, MO), B. Hammel, M. M. Chavarría, P. Maas \& H. Maas 18067 (CR, F, MO), camino nuevo entre Rancho Quemado \& Drake, B. Hammel 18287 (CR, F, INB, MO).

\section{PALICOUREA: TWO NEW SPECIES FROM COSTA RICA*}

Palicourea (Palicoureeae) comprises about 250 species of shrubs and small trees found in wet tropical forests from Mexico and the Antilles to Bolivia and northern Argentina (Taylor, 1997). Palicourea has long been considered closely related to Psychotria, but Palicourea differs from Psychotria in its persistent stipules and blue to black fruits. Palicourea has been recently classified in a separate tribe from Psychotria, Palicoureeae (Robbrecht \& Manen, 2006), though other authors have provisionally placed these all together until the entire group is better understood (Bremer \& Eriksson, 2009). Palicourea has a center of diversity in the premontane and montane habitats of southern Central America, with more than a fourth of its species found here; 44 species of Palicourea are known from Costa Rica, including the two species newly described in this article. The description format and terminology used here generally follow Taylor (1997). Keys to the species of Palicourea in Mesoamerica and Costa Rica will be presented in the forthcoming Rubiaceae treatments for the Flora Mesoamericana and Manual de Plantas de Costa Rica projects, respectively.

1. Palicourea matamana C. M. Taylor, sp. nov. TYPE: Costa Rica. Limón: cantón de Limón, Fila Matama, Valle de La Estrella, El Progreso, cabeceras del río Cariei, $9^{\circ} 47^{\prime} \mathrm{N}, 83^{\circ} 08^{\prime} \mathrm{W}$, 1400 m, 26 Apr. 1989, G. Herrera \& A. Chacón 2805 (holotype, CR; isotypes, INB, MO05016981). Figure 2A, B.

Haec species a Palicourea orosiana C. M. Taylor stipulis majoribus, lobis calycinis longioribus atque pubescentia hirsuta distinguitur.

Small trees, ca. $3 \mathrm{~m}$ tall; stems quadrate, hirsute with trichomes 1-2 mm long, becoming glabrescent. Leaves paired; blades elliptic, 10.5-17 × 4-6 cm, apex acuminate with tips $1-2 \mathrm{~cm}$, base obtuse, drying papery, adaxially glabrous, abaxially glabrous except hirsute to hirtellous along veins; secondary veins 9 to 13 pairs, free or looping to interconnect in distal part

*This section authored by Charlotte M. Taylor, Joaquín Sánchez-González, and Roy E. Gereau. 


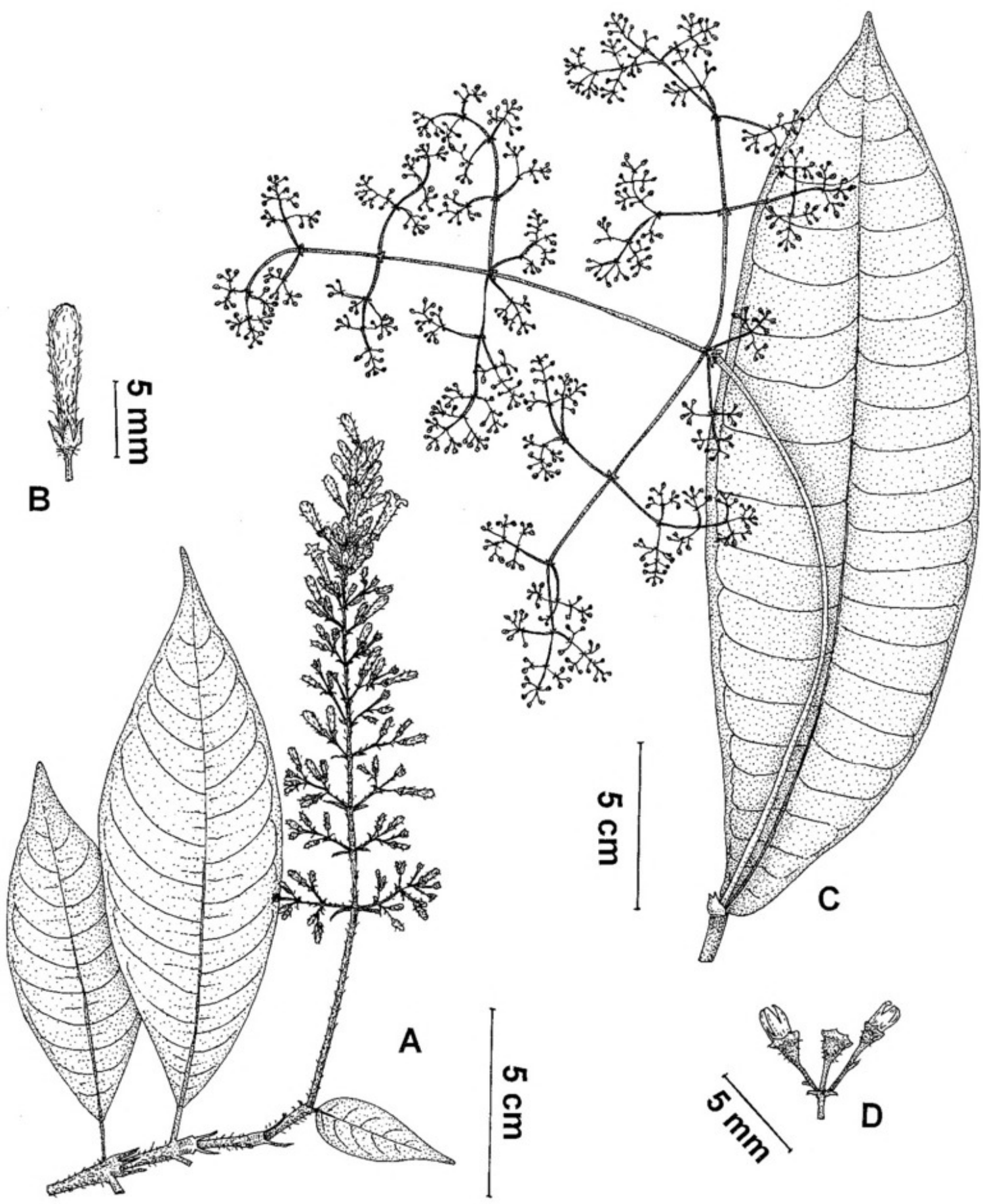

Figure 2. A, B. Palicourea matamana C. M. Taylor; based on the type Herrera \& Chacón 2805 (CR). - A. Portion of flowering branch. -B. Flower bud. C, D. Psychotria herrerana C. M. Taylor; based on the type Herrera 3306 (MO). -C. Portion of flowering branch. -D. Portion of inflorescence with one flower from which the corolla has fallen and two flowers in bud, probably near anthesis, with the lobes spreading slightly apparently as an artifact of drying.

of blade, with 1 to 2 weak intersecondary veins usually present between each pair of secondary veins, costa, secondary, and usually tertiary venation thinly prominulous adaxially, and costa and secondary veins prominent and reticulated tertiary veins prominulous abaxially; margins entire; petioles 8-16 mm, hirsute to glabrescent; stipules persistent with leaves, united around stem, hirsute, sheath truncate, 6-9 mm, lobes 2 per side, narrowly triangular to linear, 8-12 mm, acute. Inflorescence terminal, paniculiform, erect to deflexed, hirsute, dark purple or flushed with yellow; peduncle $5-6 \mathrm{~cm}$; branched portion narrowly pyramidal, $13.5-20 \times 5.5-10 \mathrm{~cm}$, with primary axis flexuous, with 10 to 11 pairs of developed secondary axes, these branched to 1 to 2 orders; bracts narrowly triangular, those subtending secondary axes 6-12 $\mathrm{mm}$, those subtending flowers $1-3.5 \mathrm{~mm}$; pedicels $3-$ $8 \mathrm{~mm}$. Flowers pedicellate in cymules of 3 to 5 ; ovary 
obconic, ca. $1 \mathrm{~mm}$, densely hirtellous to hirsute; calyx limb moderately hirtellous to hirsute, lobed nearly to base, lobes elliptic to ligulate, $1-2.5 \mathrm{~mm}$, obtuse, up to ca. $60 \%$ unequal on an individual flower; corolla tubular, pale yellow on tube and dark purple on lobes, externally densely hirsute to hirtellous, tube $10-13 \mathrm{~mm}$, lobes triangular, $2.5-3 \mathrm{~mm}$, abaxially smooth. Fruits not seen.

Habitat, distribution, and phenology. Palicourea matamana is known from wet premontane forests at ca. $1400 \mathrm{~m}$ on the eastern slopes of the Cordillera Talamanca in central Costa Rica; it has been collected with flowers in April.

IUCN Red List category. Palicourea matamana meets the criterion for Critically Endangered based on its limited $\mathrm{AOO}$ and only one known location; because there is only one collecting locality, the EOO cannot be calculated. This species was found within a legally protected area about 20 years ago. Its overall range and its rarity or frequency cannot be evaluated from this single collection. The habitat of this location is not known to be in decline, but its condition today is not well documented. Therefore, not enough information is available to assess its conservation status, and this species is considered Data Deficient (DD).

Discussion. This new species is distinguished by the combination of its hirsute stem pubescence, its well-developed stipules, its leaf blades with the veins thinly prominulous on the adaxial surface, its relatively large dark purple or yellow-flushed inflorescence, and its calyx limb with the lobes $1-2.5 \mathrm{~mm}$ long and somewhat unequal on an individual flower. Palicourea matamana is so far known from only one specimen, but is distinct from all other known species of the genus. Its type region is rich botanically, but poorly explored; the specific epithet refers to this type region.

Palicourea matamana is similar to P. orosiana C. M. Taylor, but $P$. orosiana can be recognized by its smaller stipules (with the sheath $1.5-3 \mathrm{~mm}$ long) and its longer calyx lobes (5.5-11 mm long). Palicourea matamana is also similar to P. lasiorrhachis Oerst., but $P$. lasiorrhachis can be recognized by its stipules with generally shorter lobes (1-8 mm long), its inflorescences with the branched portion generally smaller (1-15 cm long), its generally shorter calyx lobes $(0.3-1.2 \mathrm{~mm}$ long) that are generally similar in length on an individual flower, and its hirtellous or pilosulose pubescence, i.e., composed of shorter trichomes. In the classification of Taylor (1997), $P$. matamana belongs to Palicourea subg. Montanae C. M. Taylor; it is provisionally classified in section
Obovoideae C. M. Taylor based on its similarity to $P$. orosiana and $P$. lasiorrhachis of that section. However, Palicourea sect. Obovoideae is diagnosed primarily by its obovoid fruits, so this classification may change when the fruits of $P$. matamana are eventually documented.

2. Palicourea providenciana J. Sánchez-Gonz. \& C. M. Taylor, sp. nov. TYPE: Costa Rica. San José: Dota, Copey, Providencia, Zapotal, Finca Montaña Fría, $9^{\circ} 31^{\prime} 53^{\prime \prime} \mathrm{N}, 83^{\circ} 49^{\prime} 52^{\prime \prime} \mathrm{W}, 1750 \mathrm{~m}, 23$ Aug. 2004, J. Sánchez-G. \& A. Rojas 1433 (holotype, CR; isotypes, K, USJ). Figure 1C, D.

Haec species a Palicourea hammelii C. M. Taylor stipularum lobis longioribus lanceolatis, inflorescentia flava viridiflavave atque limbo calycino breviore distinguitur.

Shrubs, flowering at $0.5 \mathrm{~m}$ tall, to $3 \mathrm{~m}$ tall; stems quadrangular, glabrous. Leaves paired; blades elliptic or elliptic-oblong, 11-17.5 $\times$ 4.3-8.5 cm, apex acuminate with tips $0.5-1.2 \mathrm{~cm}$, base cuneate to obtuse, drying chartaceous, adaxially glabrous, abaxially glabrous except pilosulose or strigillose along veins; secondary veins 16 to 22 pairs, looping to interconnect in an undulating, well-developed submarginal vein situated at or up to $1 \mathrm{~mm}$ from margin, with 1(2) weak intersecondary vein(s) present between pairs of secondary veins, adaxially venation plane or costa and secondary veins thinly prominulous, abaxially costa, secondary, and submarginal veins prominulous and tertiary venation sparsely reticulated to subparallel and prominulous; margins entire; petioles $10-27 \mathrm{~mm}$, glabrous; stipules persistent with leaves, sometimes becoming indurate with age, glabrous, united around stem, sheath concave to $\mathrm{V}$-shaped between lobes, $2-5 \mathrm{~mm}$, lobes 2 per side, lanceolate, 10-17 $\times 3-6 \mathrm{~mm}$ just above base, acute to acuminate. Inflorescences terminal, paniculiform, erect to slightly deflexed, glabrous, yellow or greenish yellow; peduncle ca. $3.5 \mathrm{~cm}$; branched portion pyramidal, 2.5-6 $6 \times 3-7 \mathrm{~cm}$, with 3 to 4 pairs of developed secondary axes, these branched to 1 to 2 orders; bracts narrowly triangular to narrowly ligulate, those subtending secondary axes $6-16 \mathrm{~mm}$, those subtending flowers 5-9 mm; pedicels $1-3 \mathrm{~mm}$. Flowers pedicellate in cymules of 3 to 7 ; ovary ca. $1.5 \mathrm{~mm}$, glabrous; calyx limb glabrous, lobed essentially to base, lobes narrowly triangular, narrowly lanceolate, or narrowly ligulate, $4-6 \mathrm{~mm}$, acute to obtuse; corolla tubular, white, externally glabrous, tube $7-8 \mathrm{~mm}$, lobes triangular-ligulate, $2-3 \mathrm{~mm}$, obtuse, abaxially smooth; anthers ca. $2 \mathrm{~mm}$, situated below top of corolla tube; mature stigmas not seen. Fruits obovoid to ellipsoid, 4-6 $\times 4-5 \mathrm{~mm}$, rounded 
to a little flattened laterally, glabrous, blue; pyrenes 2 , abaxially with 3 to 4 longitudinal ridges.

Habitat, distribution, and phenology. Palicourea providenciana is known from wet premontane and montane forests at $1600-2200 \mathrm{~m}$ on the western slopes of the Cordillera de Talamanca in central Costa Rica, in the upper Río Savegre and Río Pirrís drainages; it has been collected in flower July through October, and in fruit August through December.

IUCN Red List category. Palicourea providenciana meets the criterion for Critically Endangered based on its limited EOO and for Endangered based on its limited $\mathrm{AOO}$ plus no more than five locations. This species is not found in any internationally documented protected areas, but does live within the area of the Parque Nacional Los Quetzales that is being established with the support of the local community, as discussed in the comments below. Thus, at least some of the habitat of this species can be expected to be protected into the future. This species is assessed as Vulnerable based on its limited geographic range (VU D2); however, if the habitat of its range does begin to decline, then this species will become Endangered.

Discussion. This new species is distinguished by the combination of its relatively large stipules with the lobes lanceolate (i.e., widest just above the base), its leaf blades with numerous secondary veins that connect into a well-developed submarginal vein that is set at or very close to the revolute margins, its pyramidal inflorescences that are yellow or greenish yellow and have well-developed narrow bracts, and its well-developed calyx lobes. This species is so far known from a rather limited area; its specific epithet honors the community of the type locality, whose inhabitants are working to support the Parque Nacional Los Quetzales in order to protect the biologically rich montane forests of their region (<http://www.costaricaweb.cr/es/parque-nacionallos-quetzales-costa-rica $>$ ). Palicourea providenciana is similar in particular in its inflorescence form to $P$. macrocalyx Standl., but $P$. macrocalyx can be recognized by its leaves with fewer secondary veins (nine to 13 pairs), its shorter bracts subtending the flowers (1-4 mm long), its usually shorter and broader calyx lobes (3-6 mm long) that are ovate to narrowly triangular, and its yellow or greenish yellow corollas with a generally longer tube (8-13 mm long). Palicourea providenciana can also be confused with P. hammelii C. M. Taylor, but $P$. hammelii can be recognized by its triangular stipule lobes that are shorter (4-7 mm long), its pink to purple inflorescences, its longer pedicels (4-15 mm long), its longer calyx lobes (13-20 mm long), and its longer corollas (with the tube $13-20 \mathrm{~mm}$ long). Palicourea providenciana can additionally be confused with $P$. lancifera Standl. \& L. O. Williams, but $P$. lancifera can be recognized by its shorter stipule lobes (1-5 $\mathrm{mm}$ long) and its shorter calyx lobes (1.1-3 mm long). Palicourea providenciana is also similar to $P$. orosiana, but $P$. orosiana can be recognized by its triangular calyx lobes and its generally narrower leaves (2.5-4.5 cm wide). In the classification of Taylor (1997), P. providenciana belongs to Palicourea subg. Montanae sect. Montanae, and within this section it belongs to the unnamed Series 3 and the unnamed Subseries f, together with P. macrocalyx.

Paratypes. COSTA RICA. San José: cantón Dota, estrib. NO del Cerro Lira, S. Martén \& G. Herrera 709 (CR, F); Copey, Providencia, Zapotal, Finca Montaña Fría, J. Sánchez-G. 1270 (CR), 1330 (CR); cantón Pérez-Zeledón, Páramo, camino entre San Gerardo \& Zapotal, S. Lobo 440 (CR); cantón Tarrazú, cuenca de ríos Naranjo \& Paquita, San Carlos, Alto San Jerónimo, A. Rodríguez, J. González, A. Estrada \& A. Quesada 8154 (INB); al lado de carr. hacia San Jerónimo, S. Lobo 708 (CR).

PSYCHOTRIA: A NEW SPECIES, TWO NEW COMBINATIONS, AND A NEW NAME FROM COSTA RICA AND PANAMA*

Psychotria (Psychotrieae) comprises more than 1000 species of shrubs and small trees found in seasonal and wet tropical forests worldwide (Hamilton, 1989). The Neotropical species of Psychotria have been separated into two subgenera, Psychotria subg. Psychotria and Psychotria subg. Heteropsychotria Steyerm. (Steyermark, 1972). Psychotria subg. Psychotria comprises about 200 Neotropical species found from southern Florida and northern Mexico south to northern Argentina, and corresponds to the pantropical genus Psychotria s. str.; it can be recognized by its deciduous stipules and red or orange fruits (Hamilton, 1989; Taylor, 1996a; Andersson, 2002a). Psychotria subg. Heteropsychotria comprises about 600 Neotropical species also found from Florida and northern Mexico to northern Argentina, and can be recognized by its persistent stipules and blue or black fruits. The species of these two subgenera were long included together in Psychotria (Steyermark, 1972), but recent studies show that they are better separated and that many of the species of Psychotria subg. Heteropsychotria are more closely related to Palicourea than Psychotria (Taylor, 1996a; Bremer \& Eriksson, 2009). Some

*This section authored by Charlotte M. Taylor and Roy E. Gereau. 
recent authors have classified these two subgenera in different tribes, Psychotrieae and Palicoureeae, respectively (Robbrecht \& Manen, 2006), but others have included them both in Psychotrieae until the entire group is better studied (Bremer \& Eriksson, 2009). Many of the species of Psychotria subg. Heteropsychotria are clearly better classified in Palicourea, and these generic transfers are being made as individual species groups are studied in detail (Taylor et al., 2010); however, such study has not yet been done for the species of Psychotria subg. Heteropsychotria discussed in this article. Including the newly recognized species discussed in this article, 74 species of Psychotria subg. Psychotria and 68 species of Psychotria subg. Heteropsychotria are known from Mesoamerica. The description format and terminology used here follow Taylor (2006). Keys to the species of Psychotria in Mesoamerica and Costa Rica will be presented in the forthcoming Rubiaceae treatments for the Flora Mesoamericana and Manual de Plantas de Costa Rica projects, respectively.

1. Psychotria boraginoides (Dwyer) C. M. Taylor, comb. et stat. nov. Basionym: Psychotria acuminata subsp. boraginoides Dwyer, Ann. Missouri Bot. Gard. 67: 344. 1980. TYPE: Panama. Panamá: along Cartí-El Llano-Tupile rd., 12 mi. above Panamerican Hwy., 200-500 m, 26-27 Mar. 1993, R. Liesner 1187 (holotype, MO 2164366; isotype, MO-2393472).

Discussion. Dwyer (1980) distinguished Psychotria acuminata subsp. boraginoides from $P$. acuminata Benth. subsp. acuminata based on its inflorescences with the ultimate axes unbranched or once-dichotomous, curved, reflexed, and with the flowers separated and secund along them. He did not explain the origin of the subspecific epithet, but presumably it refers to the similarity of these inflorescences to the helicoid inflorescences of some species of Boraginaceae. The inflorescence axes in both of Dwyer's subspecies of $P$. acuminata are in fact short and dichotomous initially, when the flowers are all in bud, and then elongate as the flowers and then fruits develop. The inflorescence axes typically later become helicoid in plants of $P$. acuminata subsp. boraginoides, and later become dichasial or also helicoid in $P$. acuminata subsp. acuminata. The distinctions used by Dwyer thus do not separate the two groups of plants, but the plants he included in $P$. acuminata subsp. boraginoides do differ significantly from $P$. acuminata subsp. acuminata in their leaf blades that dry stiffly papery and have the intersecondary and tertiary veins regularly developed and thinly raised on the abaxial surface, their inflorescences with the bracts all reduced or lacking, and their corollas with the tubes 6-7 mm long; versus the leaf blades drying membranous to quite thinly papery and lacking intersecondary veins or having these and the tertiary venation plane abaxially and not regularly developed, the inflorescences with several developed bracts $0.5-1 \mathrm{~mm}$ long subtending the secondary and sometimes higher-order axes, and the corollas with the tubes $2.5-5 \mathrm{~mm}$ long in $P$. acuminata subsp. acuminata. Accordingly, the plants of $P$. acuminata subsp. boraginoides are here recognized as a separate species, with the corresponding new nomenclatural combination. Psychotria boraginoides belongs to Psychotria subg. Heteropsychotria.

2. Psychotria croatii (Dwyer) C. M. Taylor, comb. nov. Basionym: Cephaelis croatii Dwyer, Ann. Missouri Bot. Gard. 67: 64. 1980. TYPE: Panama. Darién: vic. of upper gold mining camp of Tyler Kittridge on headwaters of Río Tiquesa ca. 2 air km from Cont. Divide, 26 Aug. 1972, T. B. Croat 27204 (holotype, MO2201416).

Psychotria purpureocapitata Dwyer ex C. M. Taylor, Novon 6(3): 301, fig. 2A, B. 1996, syn. nov. TYPE: Panama. Coclé: El Cope on Pacific side 1/2 hour walk from sawmill, $2400 \mathrm{ft}$. $[732 \mathrm{~m}], 16$ Oct. 1979, T. Antonio 2154 (holotype, MO 04658112).

Discussion. The plants formerly separated in Cephaelis Sw. have been shown to be a heterogeneous group, with most of them belonging to Psychotria subg. Heteropsychotria (Steyermark, 1972; Taylor, 1994), but not all (e.g., Andersson, 2002b). About 150 species of Cephaelis have been transferred to other genera (e.g., Taylor, 1994), but several dozen names remain to be studied and reclassified: the name $C$. croatii Dwyer is one of them. This name was based on a single specimen with one inflorescence from eastern Panama, a poorly explored region. This inflorescence has a well-developed peduncle and a branched portion that is shortly cymose with seven small heads (ca. $1 \mathrm{~cm}$ long), and at its basalmost node a pair of free elliptic bracts ca. $10 \times 6 \mathrm{~mm}$. The most similar Panamanian species to $C$. croatii is $P$. purpureocapitata, and these are indistinguishable vegetatively. Psychotria purpureocapitata has been recognized by its different inflorescence arrangement, capitate to subcapitate with the basalmost bracts 10 $15 \times 10-15 \mathrm{~mm}$, shortly fused at the base, and ovate, elliptic, or spatulate (Taylor, 1996b). However, study of some additional specimens reveals more variation in inflorescence arrangement than described for either of these species and also documents continu- 
ous variation that links the two inflorescence forms. In particular, the specimen J. P. Folsom, L. Collins \& G. Alonzo de Monte 6662 (MO) has inflorescences with basal bracts similar to those of $P$. purpureocapitata, but seven separate small heads, with some of these similar in their size and basalmost bracts to those of $C$. croatii, but others about twice as large, i.e., intermediate in size between $C$. croatii and $P$. purpureocapitata. Additionally, the specimen $J$. P. Folsom \& L. Collins 6446 (MO) has two inflorescences, one with the same form as that of the type specimen of $P$. purpureocapitata, and another with the same form as that of the type specimen of $C$. croatii. Therefore, all of these plants appear to belong to the same species, which has a somewhat variable inflorescence arrangement. Accordingly, these two names are synonymized here, and because $C$. croatii is the older name, a new nomenclatural combination is made here for it in Psychotria. This species belongs to Psychotria subg. Heteropsychotria.

3. Psychotria herrerana C. M. Taylor, sp. nov. TYPE: Costa Rica. Limón: cantón de Talamanca, Croriña, base \& ladera intermedia del Cerro Cruibeta, $9^{\circ} 25^{\prime} \mathrm{N}, 82^{\circ} 59^{\prime} \mathrm{W}, 700 \mathrm{~m}, 19$ July 1989, G. Herrera 3306 (holotype, INB; isotype, MO 4282346). Figure 2C, D.

Haec species a Psychotria rosulatifolia Dwyer foliis ellipticis, inflorescentia majore atque corolla minore lobis exappendiculatis distinguitur.

Small tree, ca. $3 \mathrm{~m}$ tall; stems glabrous, smooth, somewhat flattened. Leaves paired, sessile; blade elliptic, 20.5-30 $\times$ 4.5-8.5 cm, glabrous except principal veins puberulous abaxially, drying papery to subchartaceous, apex acute to weakly acuminate, base truncate to cordulate (and symmetrical); secondary veins 24 to 26 pairs, spreading at ca. $100^{\circ}-$ $120^{\circ}$ from costa, apparently without domatia, extending to unite with well-developed straight submarginal vein situated $0.5-1.5 \mathrm{~mm}$ from margin, tertiary venation not or sparsely visible, loosely reticulate; stipules caducous, not seen. Inflorescence terminal, laxly paniculiform, puberulous or shortly hirtellous to glabrescent; peduncle flexuous, ca. $16 \mathrm{~cm}$; branched portion pyramidal, ca. $25 \times 26 \mathrm{~cm}$, branched to 4 orders, axes flexuous, secondary axes 2 or 4 per node in unequal pairs; bracts subtending secondary axes deltate, ca. $2 \mathrm{~mm}$, those subtending pedicels narrowly triangular, ca. $0.5 \mathrm{~mm}$, sometimes fused in pairs; pedicels 1-2 mm. Flowers pedicellate in umbelliform cymules of 2 to 5 ; ovary portion ellipsoid to obconic, ca. $0.5 \mathrm{~mm}$, puberulous; calyx limb ca. $0.5 \mathrm{~mm}$, denticulate to shallowly lobed, puberulous to gla- brescent; corolla in bud funnelform, at anthesis greenish yellow, externally glabrous, tube to $1 \mathrm{~mm}$, internally with pilose ring just above base, lobes to $1.2 \mathrm{~mm}$, ligulate, smooth abaxially; mature anthers not seen; stigmas to ca. $1 \mathrm{~mm}$. Fruit not seen.

Habitat, distribution, and phenology. Psychotria herrerana is known from wet forest at ca. $700 \mathrm{~m}$ on the Caribbean slopes of central Costa Rica; it has been collected with flowers in July.

IUCN Red List category. Psychotria herrerana meets the criterion for Critically Endangered based on its limited $\mathrm{AOO}$ and only one known location; because there is only one collection locality, the EOO cannot be calculated. This species was found within a legally protected area about 20 years ago, in a poorly explored region. Its overall range and rarity or frequency cannot be evaluated from this single collection. The habitat of this location is not known to be in decline, but its condition today is not well documented. Therefore, not enough information is available to assess its conservation status and it is considered Data Deficient (DD).

Discussion. This new species belongs to Psychotria subg. Psychotria (Hamilton, 1989; Taylor, 2006) and is distinguished by the combination of its relatively large sessile leaves that are truncate to cordulate and clasping at the base, its numerous secondary leaf veins united into a well-developed, straight submarginal vein, its relatively large lax inflorescences borne on well-developed peduncles, and its small corollas. This striking and unusual species is named for the extraordinary Costa Rican explorer and plant collector Gerardo Herrera Chacón, who made numerous exemplary specimens of the Costa Rican flora from both accessible and remote localities. This new species is so far known from only one collection, but it is quite distinct.

Some other species of Psychotria subg. Psychotria in southern Central America have similar clasping leaves and often accumulate detritus along the stem in these cupular leaf bases. One of these is known from Costa Rica, P. chitariana Dwyer \& C. W. Ham.; however, P. chitariana can be recognized by its short, subcapitate to congestedcymose inflorescences (up to $3 \times 5 \mathrm{~cm}$ ) with the axes not developed or with the axes developed but short and only branched to one to two orders, plus its larger corollas with the tubes $4-5 \mathrm{~mm}$ long. Psychotria herrerana is also similar to $P$. rosulatifolia Dwyer of Panama, but $P$. rosulatifolia differs in its cymose inflorescences that are smaller (up to $15 \times 18 \mathrm{~cm}$ ) and generally branched to only two orders, its longer corolla tubes (2.5-4 mm long), 
and its corolla lobes that terminate in a linear appendage 1-2 mm long. Psychotria herrerana is also similar to P. insueta (Dwyer) Dwyer \& C. W. Ham., also of Panama, but $P$. insueta can be recognized by its cymose inflorescences that are smaller (up to $15 \times 18 \mathrm{~cm}$ ) and generally branched to only two orders, its longer corolla tubes (ca. 2 $\mathrm{mm}$ long), and its more numerous secondary leaf veins ( 34 to 42 pairs). Psychoria herrerana is also similar to $P$. megistophylla Standl. of western Colombia, but $P$. megistophylla can be recognized by its more numerous secondary leaf veins ( 36 to 44 pairs), its longer corolla tubes (5-6 mm long), and its corolla lobes that terminate in a linear appendage 0.5-1.5 mm long (Taylor \& Monsalve, 1997). Large and lax inflorescences similar to those of $P$. herrerana are also found in two species of Psychotria subg. Psychotria from Amazonian Ecuador, Peru, and Brazil, P. acreana K. Krause and $P$. ceronii C. M. Taylor, but both of these South American species can be recognized by their leaves with well-developed petioles and their submarginal leaf veins that are broadly looping and only weakly developed.

4. Psychotria tsakiana C. M. Taylor, nom. nov. Replaced synonym: Rudgea thyrsiflora Donn. Sm., Bot. Gaz. 61(5): 375. 1916, non Psychotria thyrsiflora Ruiz \& Pav., 1799. TYPE: Costa Rica. Limón: Talamanca, forêts de Tsâki, 200 m, Apr. 1895, A. Tonduz 9579 (holotype, US 943477; isotype, BR).

Discussion. This species was described in Rudgea Salisb. based apparently on its stipules, which have several bristles borne near the top of the sheath. The generic placement of this species was not explicitly discussed in the protologue, but $R$. thyrsiflora was classified there in Rudgea ser. Notacanthe K. Schum. Rudgea is diagnosed by stipules of varied form, though generally not bilobed, that have one to numerous, small to well-developed appendages, bristles, or segments that are glandular initially, i.e., on the youngest stipules at the stem apex (Taylor et al., 2004). These glandular appendages are variously small to well-developed on the youngest stipules, and then cease exudation of their mucilaginous or perhaps other glandular substances with age and either fall off when the leaves at that particular node are fully expanded, or become either hardened or indurate but not much enlarged on the older stipules, i.e., those at lower nodes. Rudgea ser. Notacanthe was characterized by its stipules with the glandular appendages positioned along the top of the interpetiolar portion of the sheath (vs. medially or basally). The stipules of $R$. thyrsiflora are united around the stem into a truncate sheath and have two well-developed lobes on each side, with several bristles borne adaxially (i.e., on the inside) near the top of the intrapetiolar portions of the sheath (i.e., above the petiole); these bristles become larger on the older stipules, and are generally exposed only when they become large enough to extend out from inside the stipule sheath, which shrinks as it ages or dries. Rudgea thyrsiflora is thus anomalous within Rudgea for its bilobed stipules and persistent appendages that are inserted inside the stipule. However, its persistent bilobed stipules and fruits that are purpleblack at maturity indicate its classification in Psychotria subg. Heteropsychotria, which is related to Rudgea (Robbrecht \& Manen, 2006). Accordingly, this species is here transferred to Psychotria, with the specific epithet of its new name based on the type locality.

Within Psychotria subg. Heteropsychotria, P. tsakiana is similar to the widespread Neotropical species $P$. racemosa Rich. in its stipule morphology, distinctive leaf venation with well-developed intersecondary and tertiary venation, inflorescences with the flowers sessile in small groups, relatively small corollas with the lobes abaxially horned or appendaged, and drupaceous fruits that are orange when immature then turn black and have five (rather than two) pyrenes that are triangular in cross section. However, $P$. tsakiana can be separated from $P$. racemosa by its narrowly pyramidal to racemiform inflorescences and its longer corollas (with the tube 4-5 mm long), versus broadly pyramidal, cymose to paniculiform inflorescences and shorter corollas (with the tube $2.5-3 \mathrm{~mm}$ long) in P. racemosa. Psychotria tsakiana is also similar to $P$. stenostachya Standl. of the western Amazon basin, but P. tsakiana is so far only known from Costa Rica and can be recognized by its longer calyx limb $(0.8-1 \mathrm{~mm}$ long) and its larger corollas (with the tube $2.5-3 \mathrm{~mm}$ long), versus the calyx limb ca. $0.5 \mathrm{~mm}$ long and the corollas with the tube $1.5-3 \mathrm{~mm}$ long in $P$. stenostachya.

\section{SIMIRA: A NEW NOMENCLATURAL COMBINATION FOR A} PANAMANIAN SPECIES*

Dwyer and Hayden (1968) described Bathysa panamensis Dwyer based on a flowering collection from eastern Panama, N. Bristan 1187 (MO). The classification of this species in Bathysa C. Presl was not explained, and at that time Bathysa had not been reported from Central America (Standley, 1938) or

*This section authored by Charlotte M. Taylor. 
northwestern South America (Standley, 1930, 1931a, 1931b), although it was known from Peru and Bolivia (Standley, 1938). The single specimen of $B$. panamensis lacks stipules and fruits, and has a complete inflorescence with flowers in bud and at anthesis. The corolla lobes are imbricate in bud, and the floral characters of this plant are congruent with several genera of Neotropical Rubiaceae, but are not alone diagnostic for any single genus (Taylor et al., 2004). Subsequently, Dwyer (1980) recognized one species of Bathysa in Panama, B. veraguensis Dwyer, a different species from $B$. panamensis; the name $B$. panamensis was not cited in that work at all, but he did treat there the specimen $N$. Bristan 1187 as the type of a newly described species, Simira darienensis Dwyer, apparently without realizing that this same specimen was the type of his other name. Consequently, the name $S$. darienensis is superfluous and illegitimate, because it includes the type of a previously published valid name. [This is not the only such case in this work (e.g., Taylor, 1989).]

Simira darienensis was documented with two specimens, which clearly both belong to the same species, and the second specimen, J. Duke 8606 (MO), has immature fruits. These fruits are woody and apparently capsular, and are rather large for Rubiaceae capsules (ca. $1.5 \times 1 \mathrm{~cm}$ ). One of these fruits is partially opened and shows the several developing seeds, which are flat, about as wide as the capsule, and arranged in a vertical stack with one on top of another. This fruit morphology and in particular this seed form and arrangement are diagnostic for Simira Aubl. (Taylor et al., 2004). In contrast, the fruits of Bathysa are smaller and more thinly woody capsules, generally $3-5 \times 3-5 \mathrm{~mm}$, with the seeds much smaller than the width of the capsule, angled, and packed irregularly inside the locule (Germano Filho, 1998). Thus, this species belongs in Simira, and the corresponding new combination is made here.

Simira panamensis (Dwyer) C. M. Taylor, comb. nov. Basionym: Bathysa panamensis Dwyer, Ann. Missouri Bot. Gard. 55: 34. 1968. Simira darienensis Dwyer, Ann. Missouri Bot. Gard. 67: 493. 1980, nom. illeg. TYPE: Panama. Darién: Río Ucurganti, 7 July 1967, N. Bristan 1187 (holotype, MO 198219).

Acknowledgments. We thank the curators of the herbaria cited above and the managers of several floristic projects for kindly providing access to materials; W. C. Burger and M. Grayum for helpful information and comments; the Museo Nacional de Costa Rica, INBio, and the grant "Desarrollando capacidades y compartiendo tecnología para la gestión de la biodiversidad en Centroamérica" of the Norwegian Ministry of Foreign Affairs for support and logistical help for travel by the first author to those two institutions; the Botanical Latin Working Group of the Science and Conservation Division, Missouri Botanical Garden, for help with the Latin translations; and R. Magill and O. M. Montiel for significant facilitation of this work.

\section{Literature Cited}

Andersson, L. 2002a. Relationships and generic circumscriptions in the Psychotria complex (Rubiaceae, Psychotrieae). Syst. Geogr. Pl. 72: 167-202.

Andersson, L. 2002b. Re-establishment of Carapichea (Rubiaceae, Psychotrieae). Kew Bull. 57: 363-374.

Borhidi, A. 2006. Rubiáceas de México. Akadémiai Kiadó, Budapest.

Bremer, B. \& T. Eriksson. 2009. Time tree of Rubiaceae: Phylogeny and dating the family, subfamilies, and tribes. Int. J. Pl. Sci. 170(6): 766-793.

Croat, T. B., W. H. Lewis \& P. Bernhardt. 2006. John Dwyer (1915-2005). Taxon 55(2): 543-544.

Cuatrecasas, J. 1953. Caracterización del género Borojoa. Acta Agron. 3: 89-98.

Dwyer, J. D. 1980. Rubiaceae. In R. E. Woodson \& R. E. Schery (editors), Flora of Panama. Ann. Missouri Bot. Gard. 67: 1-522.

Dwyer, J. D. \& M. V. Hayden. 1968. New and noteworthy woody Rubiaceae from Panama. Ann. Missouri Bot. Gard. 55: $34-47$.

ESRI (Environmental Systems Research Institute). 1999. ArcView GIS 3.2. ESRI, Redlands, California.

Germano Filho, P. 1998. Estudos taxonômicos do gênero Bathysa C. Presl (Rubiaceae, Rondeletieae), no Brasil. Rodriguesia 50(76/77): 49-75.

Hamilton, C. 1989. A revision of Mesoamerican Psychotria subg. Psychotria (Rubiaceae). Ann. Missouri Bot. Gard. 76: 67-111, 386-429, 886-916.

IUCN. 2001. IUCN Red List Categories and Criteria, Version 3.1. Prepared by the IUCN Species Survival Commission. IUCN, Gland, Switzerland, and Cambridge, United Kingdom.

IUCN Standards and Petitions Working Group. 2008. Guidelines for Using the IUCN Red List Categories and Criteria, Version 7.0. IUCN, Gland, Switzerland, and Cambridge, United Kingdom.

Lorence, D. H. 1999. A Nomenclator of Mexican and Central American Rubiaceae. Monogr. Syst. Bot. Missouri Bot. Gard. 73.

McNeill, J., F. R. Barrie, H. M. Burdet, V. Demoulin, D. L. Hawksworth, K. Marhold, D. H. Nicolson, J. Prado, P. C. Silva, J. E. Skog, J. H. Wiersema \& N. J. Turland (editors). 2006. International Code of Botanical Nomenclature (Vienna Code). Regnum Veg. 146.

Moat, J. 2007. Conservation assessment tools extension for ArcView 3.x, version 1.2. GIS Unit, Royal Botanic Gardens, Kew, Richmond. <http://www.kew.org/gis/ projects/cats/catsdoc.pdf $>$, accessed 10 January 2011.

Persson, C. 2000. Phylogeny of the Neotropical Alibertia group (Rubiaceae), with emphasis on the genus Alibertia, inferred from ITS and 5S ribosomal DNA sequences. Amer. J. Bot. 87(7): 1018-1028. 
Robbrecht, E. \& J.-F. Manen. 2006. The major evolutionary lineages of the coffee family (Rubiaceae, angiosperms). Combined analysis (nDNA and cpDNA) to infer the position of Coptosapelta and Luculia, and supertree construction based on $r b c L, r p s 16, \operatorname{trn} L-t r n F$ and $a t p B$ $r b c L$ data. A new classification in two subfamilies, Cinchonoideae and Rubioideae. Syst. Geogr. Pl. 76: 85146.

Schulman, L., T. Toivonen \& K. Ruokolainan. 2007. Analysing botanical collecting effort in Amazonia and correcting for it in species range estimation. J. Biogeogr. 34: 1388-1399.

Standley, P. C. 1930. The Rubiaceae of Colombia. Publ. Field Columbian Mus., Bot. Ser. 7(1): 1-175.

Standley, P. C. 1931a. The Rubiaceae of Ecuador. Publ. Field Columbian Mus., Bot. Ser. 7(2): 179-251.

Standley, P. C. 1931b. The Rubiaceae of Venezuela. Publ. Field Columbian Mus., Bot. Ser. 7(4): 343-485.

Standley, P. C. 1938. Rubiaceae. In Flora of Costa Rica. Publ. Field Mus. Nat. Hist., Bot. Ser. 18: 1264-1380.

Steyermark, J. A. 1966. The genus Borojoa in Venezuela. Bol. Soc. Venez. Ci. Nat. 110: 474-479.

Steyermark, J. A. 1972. Rubiaceae. In B. Maguire \& collaborators (editors), The Botany of the Guyana Highland, Part IX. Mem. New York Bot. Gard. 23: 227-832.

Taylor, C. M. 1989. Revision of Palicourea (Rubiaceae) in Mexico and Central America. Syst. Bot. Monogr. 26: 1102.

Taylor, C. M. 1994. Taxonomic notes on Psychotria (Rubiaceae) in western South America. Novon 4: 303 306.

Taylor C. M. 1996a. Overview of the Psychotrieae (Rubiaceae) in the Neotropics. Opera Bot. Belg. 7: 261-270.
Taylor, C. M. 1996b. More new species and a new combination in Rubiaceae from Costa Rica and Panama. Novon 6(3): 298-306.

Taylor, C. M. 1997. Conspectus of the genus Palicourea (Rubiaceae: Psychotrieae) with the description of some new species from Ecuador and Colombia. Ann. Missouri Bot. Gard. 84: 224-262.

Taylor, C. M. 2001. Overview of the Neotropical genus Notopleura (Rubiaceae: Psychotrieae) with the description of some new species. Ann. Missouri Bot. Gard. 88: 478-515.

Taylor, C. M. 2003. Rubiacearum americanarum magna hama pars XV. New species and two new combinations in Notopleura (Psychotrieae) from Central and South America. Novon 13: 228-260.

Taylor, C. M. 2004. The Neotropical genus Ronabea (Rubiaceae, Lasiantheae). Syst. Geogr. Pl. 74: 35-42.

Taylor, C. M. 2006. Rubiacearum americanarum magna hama pars XVIII: New species of Psychotria subg. Psychotria from Central America and western South America. Novon 16: 142-154.

Taylor, C. M. \& M. Monsalve B. 1997. Una especie nueva y descripciones ampliadas de dos especies poco conocidas en Rubiaceae de la región fitogeográfica del Chocó de Colombia y Ecuador. Novon 7: 201-207.

Taylor, C. M., J. A. Steyermark, P. G. Delprete, A. Vincentini, R. Cortés, D. Zappi, C. Persson, C. Bestetti Costa \& E. Araujo da Anunciação. 2004. Rubiaceae. Pp. 497-847 in P. E. Berry, K. Yatskievych \& B. K. Holst (editors), Flora of the Venezuelan Guayana, Vol. 8. Missouri Botanical Garden Press, St. Louis.

Taylor, C. M., D. H. Lorence \& R. E. Gereau. 2010. Rubiacearum americanarum magna hama pars XXV: The nocturnally flowering Psychotria domingensis-Coussarea hondensis group plus three other Mesoamerican Psychotria species transfer to Palicourea. Novon 20(4): 481492. 


\section{$2 \mathrm{BHL}$ Biodiversity Heritage Library}

Taylor, Charlotte M. et al. 2011. "Rubiacearum Americanarum Magna Hama Pars XXVIII: New Taxa, New Combinations, New Names, and Lectotypification for Several Species Found in Mexico and Central America." Novon a journal of botanical nomenclature from the Missouri Botanical Garden 21(1), 133-148. https://doi.org/10.3417/2009129.

View This Item Online: https://www.biodiversitylibrary.org/item/180102

DOI: https://doi.org/10.3417/2009129

Permalink: https://www.biodiversitylibrary.org/partpdf/218465

\section{Holding Institution}

Missouri Botanical Garden, Peter H. Raven Library

\section{Sponsored by}

Missouri Botanical Garden

\section{Copyright \& Reuse}

Copyright Status: Permission to digitize granted by rights holder

Rights: https://www.biodiversitylibrary.org/permissions

This document was created from content at the Biodiversity Heritage Library, the world's largest open access digital library for biodiversity literature and archives. Visit BHL at https://www.biodiversitylibrary.org. 